(D) HTTP://ORCID.ORG/ 0000-0002-0572-2673

MONIKA COGHEN

Uniwersytet Jagielloński

e-mail: monika.coghen@uj.edu.pl

\title{
Manfred 1892 na scenie Teatru Wielkiego w Warszawie
}

\section{The 1892 Manfred in Warsaw Teatr Wielki}

\begin{abstract}
Byron claimed that Manfred had not been intended for the stage, but his dramatic poem was occasionally produced in the nineteenth-century theatre. In 1848 Robert Schumann adapted the poem for stage performance, composing the Overture and incidental music. Schumann's version of Manfred was staged in Warsaw Teatr Wielki, with Józef Kotarbiński, a wellknown actor, theatre manager and critic as the protagonist. The production was followed by a heated debate in the press. The central controversy focused on whether Byron's "metaphysical drama" was suitable for the stage and relevant for the late nineteenth-century Polish audience. The aim of this paper is to examine central issues in this debate by scrutinizing the press reviews of the Warsaw production. As the reviews are by their very nature subjective, their examination reveals much more about their authors' literary and theatrical preferences than about the performance itself, and provides an insight in the early stages of the development of the so-called Young Poland movement (Młoda Polska), with its emphasis on individualism and subjectivity, interest in metaphysics, and prevalence of lyricism. The 1892 Manfred in Warsaw may be seen as an attempt at introducing great Romantic poetry in the theatre, paving the way for the theatre productions of Polish Romantic drama, which Kotarbiński was to stage as the manager of Teatr Miejski in Kraków. The article also contributes to the history of Byron's reception in Poland.
\end{abstract}

Keywords: Manfred, Byron, Robert Schumann, Józef Kotarbiński, Teatr Wielki in Warsaw, theatre criticism, Byron's reception in Poland

\begin{abstract}
Abstrakt: Byron twierdził, że Manfred nie był przeznaczony na scenę, ale jego poemat dramatyczny był sporadycznie wystawiany w dziewiętnastowiecznym teatrze. W 1848 roku Robert Schumann zaadaptował poemat do wykonania scenicznego, skomponował uwerturę i muzykę incydentalną. Manfreda w wersji Schumanna wystawiono w warszawskim Teatrze Wielkim z Józefem Kotarbińskim, znanym aktorem, kierownikiem teatru i krytykiem, w roli głównej. Po realizacji rozgorzała gorąca debata w prasie. Główny spór dotyczył tego, czy „dramat metafizyczny" Byrona nadaje się na scenę i czy jest istotny dla polskiej publiczności końca XIX wieku. Celem niniejszego artykułu jest zbadanie głównych kwestii podejmowanych w tej debacie poprzez analizę recenzji tej realizacji w prasie warszawskiej. Ponieważ recenzje są z natury subiektywne, ich badanie ujawnia znacznie więcej preferencji literackich i teatralnych
\end{abstract}


ich autorów niż informacji o samym spektaklu i daje wgląd we wczesne etapy rozwoju tzw. Młodej Polski, z naciskiem na indywidualizm i podmiotowość, zainteresowanie metafizyką i dominację liryzmu. Warszawskiego Manfreda z 1892 roku można więc uznać za próbę wprowadzenia do teatru wielkiej poezji romantycznej, torującej drogę teatralnym inscenizacjom polskiego dramatu romantycznego, który Kotarbiński miał wystawić jako dyrektor Teatru Miejskiego w Krakowie. Artykuł wpisuje się także w historię recepcji Byrona w Polsce.

Słowa kluczowe: Manfred, Byron, Robert Schumann, Józef Kotarbiński, Teatr Wielki, krytyka teatralna, recepcja Byrona w Polsce

$* * *$

Manfred często bywa uważany za najpełniejsze przedstawienie bohatera byronicznego ${ }^{1}$. Peter Thorslev uznał protagonistę poematu dramatycznego Byrona za reprezentatywnego bohatera romantyzmu, łączącego w sobie cechy większości typów postaci literackich symptomatycznych dla epoki, takich jak Faust, Kain, Żyd Wieczny Tułacz i Szatan-Prometeusz². Zarówno dziewiętnastowieczni krytycy - wśród polskich ludzi pióra Józef Kotarbiński - jak i piszący w XXI wieku niemiecki badacz Rolf Lessenich widzą w nim obraz nowoczesnej kondycji ludzkiej. Według Kotarbińskiego,

w Manfredzie i Kainie [Byron] wcielił swe najwyższe pomysły w stylu „metafizycznym”, jak go sam nazywa, postawił ideał niepodległości człowieka, który we własnym wnętrzu nosi trybunał moralny, nieuległy potęgom przesądu, a nawet przeznaczenia, wypowiedział wiekuisty protest rozumu ludzkiego, przeciw krępującym go dogmatom ${ }^{3}$.

Lessenich widzi w Manfredzie intelektualistę targanego potężnymi namiętnościami, odmawiającego poddania się losowi, który go zniewala ${ }^{4}$. W twórczości polskich romantyków łatwo można się doszukać powinowactw z Manfredem. Wystarczy przywołać Wacława dzieje Stefana Garczyńskego, Dziady Adama Mickiewicza, Kordiana i W Szwajcarii Juliusza Słowackiego czy Nie-boska komedię Zygmunta Krasińskiego ${ }^{5}$. W latach 1835-1885 ukazało się pięć przekładów poematu na język polski (Edmunda Bojanowskiego, Józefa Paszkowskiego, Franciszka Morawskiego, Michała Chodźki i Stanisława Rzętkowskiego). Inscenizacja Manfreda w Teatrze Wielkim, z ilustracją muzyczną Roberta Schumanna, w Warszawie w 1892 roku często bywa wymieniana jako jedno z większych

${ }^{1}$ S. Chew, Jr., The Dramas of Lord Byron, Göttingen 1915, s. 75; P.J. Manning, Byron and His Fictions, Detroit 1978, s. 71.

${ }^{2}$ P.L. Thorslev, Jr., The Byronic Hero. Types and Prototypes, Minneapolis 1962, s. 166-167.

3 J. Kotarbiński, Byrona ,Don Juan” i Stowackiego „Beniowski”, „Ateneum” 1889, r. 14, t. 2, z. 1, s. 12, https://crispa.uw.edu.pl/object/files/410142/display/Default (dostęp: 29.04.2021).

${ }^{4}$ R.P. Lessenich, Drama and Theater [w:] Byron in Context, red. C. Tuite, Cambridge 2020, s. 225.

${ }_{5}^{5}$ Zob. S. Windakiewicz, Walter Scott i Lord Byron w odniesieniu do polskiej poezji romantycznej, Kraków 1914, s. 187-206; R. Pakowska, Polskie przekłady poematów Byrona "Childe Harold" $i$ "Manfred", Kraków 1938, s. 9-10; V. Erlich, The Conception of the Poet in Krasiński and the Romantic Myth of the Artist, ,Studies in Romanticism” 1962 (Summer), t. 1, nr 4, s. 199-200, Jstor (dostęp:1 8.10.2013). 
osiągnięć teatralnych tego okresu' ${ }^{6}$ Rzadziej mówi się o burzliwej polemice wokół przedstawienia w warszawskiej prasie, chociaż została ona upamiętniona w felietonie Bolesława Prusa Awantura z powodu Manfreda ${ }^{7}$.

Cytowany powyżej Józef Kotarbiński - literat i wszechstronny człowiek teatru - którego kreacja Manfreda wymieniana jest zwykle wśród jego najwybitniejszych osiągnięć aktorskich obok Fausta, Hamleta i Uriela Acosty ${ }^{8}$, po latach miał ambiwalentne odczucia wobec tego przedstawienia. W 1926 roku w swoich wspomnieniach pisał o doświadczeniach teatralnych z Byronem, którego wprowadził na polską scenę jako ,reżyser repertuaru”, innymi słowy kierownik artystyczny:

Gdy wystawiliśmy na scenie Teatru Wielkiego Manfreda Byrona z muzyką Schumanna, wytoczono reżyserii hałaśliwą kampanię, chociaż wykonanie poematu z udziałem orkiestry operowej Münchheimera stało na poziomie europejskim. Co prawda Manfred jako widowisko teatralne nie był ponętny dla szerszej publiczności, tylko dla ludzi wybredniejszego smaku. [...]

Gdy Manfred kasowo nie dał dobrych rezultatów i zawiodła inna jeszcze sztuka w Teatrze Wielkim, ustąpił Ładnowski razem ze mną w r[oku] $1892^{9}$.

Kotarbiński nie mówi nic o własnej kreacji aktorskiej, koncentruje się natomiast na starciu z warszawskimi krytykami teatralnymi, którzy według niego byli uprzedzeni wobec jego kierownictwa artystycznego teatru, bo był zarówno krytykiem literackim, jak i aktorem ${ }^{10}$. Z tej wypowiedzi przebija rozgoryczenie recepcją przedstawienia; sugeruje, że klęska finansowa doprowadziła do rezygnacji ze stanowiska zarówno jego, jak i jego współpracownika Bolesława Ładnowskiego, który był odpowiedzialny za inscenizację.

Warszawskie wystawienie Manfreda oraz dyskusja, którą sprowokowało, dają ciekawy wgląd w dzieje recepcji Byrona w Polsce oraz w historię polskiego teatru i krytyki teatralnej. Sam Kotarbiński, który - jak się wydaje - był głównym duchem sprawczym tego przedsięwzięcia, stawiał sobie za cel podniesienie poziomu artystycznego sceny warszawskiej. Prawdopodobnie myślał, że poprzez atrakcyjny wizualnie i muzycznie spektakl oparty na dziele, którego echa można

${ }^{6}$ Zob. M.O. Bieńka, Od zenitu do zmierzchu. Teatr warszawski 1880-1919, Warszawa 2015, s. $137-138$.

${ }^{7}$ W. Krajewska, Recepcja literatury angielskiej w Polsce w okresie modernizmu (1887-1918), Wrocław 1972, s. 60. Zdaniem Krajewskiej, „spór o bohatera bajronicznego, jakie wywołało wystawienie w Teatrze Wielkim Manfreda w 1892 r. [...] dobrze ilustruje zmieniające się poglądy na twórczość autora. Pomysł grania tego dramatu wydawał się recenzentom chybiony, bo owa «kwintesencja romantycznego bólu» była współczesnej publiczności całkowicie obca”. Krajewska sąd swój opiera na felietonie Prusa, który odczytuje jako jednoznacznie negatywny, nie biorąc pod uwagę wypowiedzi krytyków, takich jak Władysław Bogusławski i Cezary Jellenta, przedstawionych przeze mnie w tym artykule.

${ }^{8} \mathrm{Na}$ przykład biogram opracowany przez Mariolę Szydłowską, Józef Kotarbiński [w:] Encyklopedia teatru polskiego, 2018, https://www.encyklopediateatru.pl/osoby/26730/jozefkotarbinski (dostęp:16.03.2021).

9 J. Kotarbiński, Ze świata ułudy. Wybór pism teatralnych, wybór i opracowanie D. Kosiński, Kraków 2012, s. 159, 160.

${ }^{10}$ Ibid., s. 159. 
znaleźć u polskich romantyków, uda mu się przyciągnąć szeroką widownię. Nie mogąc wystawić w Warszawie Dziadów ani Kordiana sięgnął po utwór Byrona.

O ile mi wiadomo, nie zachowała się dokumentacja z tego przedstawienia; w związku z czym spróbuję opisać jego główne cechy na podstawie, często bardzo sprzecznych, recenzji prasowych. Z natury rzeczy artykuły te są subiektywne i często mówią więcej o gustach estetyczno-literackich ich autorów niż o samym spektaklu. Ukazują one, moim zdaniem, przede wszystkim debatę o miejscu dramatu poetyckiego i sztuki wysokiej na polskiej scenie. Można w nich dostrzec sygnały wyłaniającego się w tym okresie modernizmu ${ }^{11}$, na co wskazują uwagi recenzentów, takich jak Władysław Bogusławski ${ }^{12}$ i Cezary Jellenta ${ }^{13}$, o aktualności Manfreda dla młodego pokolenia.

Spór wokół Manfreda rozpoczął się jesienią 1891 roku, kiedy po gruntownej przebudowie otwarto Teatr Wielki w Warszawie. Krytyk teatralny i autor popularnych komedii społeczno-obyczajowych, Kazimierz Zalewski, na łamach „Kuriera Warszawskiego" zaatakował plany repertuarowe nowego kierownictwa artystycznego ${ }^{14}$ : „Dramat dotąd śpi - a co prawda i pojawiające się zapowiedzi nowych utworów wyglądają na majaczenia senne”. Przez „majaczenia senne” Zalewski miał na myśli głównie plany wystawienia dzieła Byrona. Zdaniem krytyka:

Zabytek to pierwocin romantyzmu, który dla smakoszy literackich, jakimi są Niemcy, nie pojawia się nigdzie od lat kilkunastu na tamtejszych scenach, pomimo wspaniałej ilustracji muzycznej Schumanna. W jednym Burgu wiedeńskim grywają go co lat parę zaledwie i to przy wyjątkowych uroczystościach. Mamy co prawda coś cztery przekłady Manfreda

11 Używam tu terminu ,modernizm” w znaczeniu, w jakim tego słowa używał Kazimierz Wyka, określając nim „wcześniejszą, przygotowawczą fazę twórczości pokolenia Młodej Polski, fazę związaną przede wszystkim z powstaniem indywidualizmu, z odrodzeniem metafizyki, z przesyceniem rodzajów literackich liryzmem i symboliką" oraz sugerując ramy czasowe 1887-1903 dla tego zjawiska w monografii Młoda Polska, T. 1: Modernizm polski (1958), wyd. II, Kraków 1987, s. 30. Oczywiście biorąc pod uwagę przedmiot debaty - inscenizację dramatycznego poematu Byrona - narzuca się określenie nowych zjawisk literackich mianem neoromantyzmu, jak zrobił to Julian Krzyżanowski w swojej klasycznej monografii Neoromantyzm polski 1890-1918 (wyd. 3, Wrocław 1980). Większość badaczy, takich jak Maria Podraza-Kwiatkowska (Literatura Młodej Polski, Warszawa 2000, s. 5) i Artur Hutnikiewicz (Młoda Polska, Warszawa 2004, s. 68-69), przyjmuje rok 1890 jako umowny początek Młodej Polski, wskazując równocześnie na umowność tej daty. W swoim studium o młodopolskiej krytyce literackiej Michał Głowiński, podkreślając płynność granic czasowych, zauważa, że niekiedy w ,sposobach myślenia i pisania” autorów negatywnie nastawionych do nowych tendencji w literaturze ,pojawiają się elementy, jakie - czasem w przekształconej postaci - okażą się ważne dla tych sposobów uprawiania krytyki, które się skrystalizowały na przełomie wieków" (M. Głowiński, Ekspresja i empatia. Studia o młodopolskiej krytyce literackiej, Kraków 1997, s. 14).

12 Według Encyklopedii teatru polskiego, Bogusławski ,[b]ył krytykiem oryginalnym, wszechstronnie wykształconym, eklektykiem o szerokich horyzontach myślowych i artystycznych, nie związanym bliżej z żadnym kierunkiem literackim, choć często zaliczanym do idealistów (np. przez Wilhelma Feldmana)", http://www.encyklopediateatru.pl/osoby/4999/wladyslaw-boguslawski (dostęp: 2.09.2021).

13 Cezary Jellenta (pierw. Napoleon Hirschband), jeden z ważniejszych, choć mniej znanych, przedstawicieli krytyki młodopolskiej, który jest przedmiotem monografii T. Lewandowskiego, Cezary Jellenta, esteta i krytyk. Działalność w latach 1880-1914, Wrocław 1975.

${ }^{14}$ Kotarbiński od 1891 roku pełnił funkcję ,reżysera repertuaru” w teatrach rządowych. Z. Jasińska, Józef Kotarbiński, Warszawa 1969, s. 12. 
(Michała Chodźki, Odyńca, Bojanowskiego i hr. Kustera ${ }^{15}$ ). Jest więc w czym wybierać i to może nęci reżyserię ${ }^{16}$.

Zalewski ostrzegał, że utwór jest niesceniczny, a długie monologi Manfreda mogą zabrzmieć nutą, ,nudną i ckliwą" dla widowni końca XIX wieku. Po co sięgać po poemat dramatyczny Byrona, kiedy ma się do dyspozycji sztuki Szekspira? Co więcej, kierownictwo teatru szło na łatwiznę, sięgając po tekst łatwo dostępny w przekładzie ${ }^{17}$.

Kotarbiński natychmiast zareagował na atak Zalewskiego odpowiedzią opublikowaną w trzech dziennikach - „Kurierze Porannym,” „Kurierze Codziennym” oraz „Słowie"18, gdyż redakcja "Kuriera Warszawskiego” odmówiła opublikowania jego riposty, co wyraźnie wskazuje na rozmaite powiązania poszczególnych czasopism. Stanowczo bronił własnych wyborów repertuarowych, zarzucając Zalewskiemu przedstawienie błędnych informacji. Jak podkreślał, Manfred był stałą pozycją w repertuarze teatru w Monachium, ze słynnym aktorem Ernstem Possartem w roli tytułowej, a w Paryżu, gdzie wystawiany był jako kantata, ,rolę tytułową deklamuje Mounet-Sully"19. Zalewski wykazał się również ignorancją, podając błędnie nazwiska polskich tłumaczy Manfreda - został pominięty przekład autorstwa Odyńca:

Ponieważ najlepszy z dawniejszych przekładów Fr. Morawskiego (pominięty przez recenzenta) okazał się przestarzałym, pod względem literackim i nie odpowiadał rytmice oryginału, do której stosuje się muzyka Schumana [sic], przeto na żądanie poprzedniej reżyserii jeszcze przed rokiem przekładu tego dokonał p. Gabriel Kempner, stosując się do znakomitej kompozycji muzycznej, która potęguje efekt wykonania tragedii ${ }^{20}$.

Ta może błaha na pierwszy rzut oka polemika po premierze Manfreda rozrosła się w szeroką debatę krytyczną w warszawskiej prasie. Z jednej strony mamy do czynienia z przekonaniem, że poemat Byrona to produkt minionej epoki, który nie odpowiada zainteresowaniom ówczesnej widowni, z drugiej że przedstawia ważną pozycję repertuaru sceny europejskiej. Zalewski twierdził, że Kotarbiński idzie na łatwiznę, ponieważ istnieje wiele polskich przekładów - przy czym wykazał się nieznajomością tematu ${ }^{21}$.

${ }^{15}$ Nie udało mi się ustalić, kim był wspomniany przez Zalewskiego hr. Kuster.

${ }^{16}$ K. Zalewski, Z teatru (Dokończenie), „Kurier Warszawski” 1891, r. 71, nr 271, s. 2, https:// crispa.uw.edu.pl/object/files/163105/display/Default (dostęp: 30.03.2021).

17 Ibid.

18 J. Kotarbiński, Art. nad., „Kurier Poranny”, 1891, r. 15, nr 279, s. 2, https://crispa.uw.edu.pl/ object/files/133709/display/Default (dostęp: 20.03.2021); idem, Listy do redakcji, „Kurier Codzienny” 1891, r. 27, nr 278, s. 2, https://polona.pl/item/kurjer-codzienny-r-27-nr-278-8-pazdziernika-1891,ND EwMzgyMDc/0/\#info:metadata (dostęp: 30.03.2021); idem, Listy do redakcji „Stowa”, „Słowo” 1891, r. 10, nr 224, s. 3, https://polona.pl/item/slowo-r-10-nr-224-9-pazdziernika-1891,MTU3NjI3N zU/0/\#info:metadata (30.03.2021).

${ }_{19}$ Manfred. THEATREONLINE.com, https://www.theatreonline.com/Spectacle/Manfred/43084 (dostęp: 30.04.2021).

${ }^{20}$ J. Kotarbiński, Art. nad., s. 2.

${ }^{21}$ Maria Olga Bieńka przypisuje decyzję o wystawieniu Manfreda Kotarbińskiemu: eadem, Warszawskie teatry rządowe. Dramat i komedia 1890-1915, Warszawa 2003, s. 247. Kotarbiński we 
Decyzja o wystawieniu Manfreda wynikała z dążenia zarządu Teatru do wprowadzenia na scenę narodową dramatu poetyckiego i zamiłowania Kotarbińskiego do poezji romantycznej. Kotarbiński miał bardzo wysoką opinię o twórczości Byrona, co zaznaczył w cytowanym wcześniej eseju o Don Juanie, opublikowanym w „Ateneum” w 1889 roku. W 1880 roku występował w roli Fausta i, mimo mieszanego przyjęcia przez krytykę, do tej roli powracał wiele razy w swojej karierze $^{22}$. Wielki sukces osiągnął jako Hamlet (1889). Współcześni opisywali go jako ,subtelnego deklamatora, głęboko wnikającego w treść utworu”23. Dla miłośnika romantyzmu, obeznanego z repertuarem teatrów europejskich, Manfred z ilustracją muzyczną Schumanna był kuszącą pozycją, szczególnie po Fauście i Hamlecie, których tradycję - o czym wiedział wszechstronnie oczytany Kotarbiński - Manfred kontynuuje. Było to ogromne przedsięwzięcie, które wymagało nie tylko zamówienia kolejnego tłumaczenia, a właściwie adaptacji poematu Byrona, ale również nowych dekoracji i oprawy muzycznej. Dzięki nowej scenie o dobrej akustyce wyposażonej w nowoczesne oświetlenie i maszynerię ${ }^{24}$, taki spektakl stał się możliwy.

\section{Manfred a teatr}

Manfred nie gościł często na deskach scenicznych. Nie ma w tym nic zaskakującego - już sam Byron podkreślał, że utwór nie był przeznaczony do wykonania. Poeta miał ambiwalentny stosunek do inscenizacji swoich dzieł dramatycznych. Z jednej strony, jako członek komitetu zarządzającego teatrem Drury Lane, świetnie znał realia teatralne i ówczesny repertuar, sam będąc odpowiedzialny za wybór wystawianych utworów. Z drugiej zaś strony, w swojej korespondencji zarzekał się, że jego własne utwory dramatyczne nie są przeznaczone na scenę, określając je terminem mental theatre - „teatr wyobraźni”25.

W liście do Johna Murraya z 15 lutego 1817 roku - na który często powoływali się warszawscy krytycy - Byron, ze swą charakterystyczną autoironią, informował swojego wydawcę o świeżo ukończonym poemacie dramatycznym:

wspomnieniach pisze, że inicjatorem wystawienia Manfreda był Jan Tatarkiewicz: J. Kotarbiński, Ze świata utudy..., s. 159-160.

${ }^{22}$ Z. Jasińska, op. cit., s. 28-29

${ }^{23}$ A. Leo, Wczoraj. Gawęda z niedawnej przeszłości, Warszawa 1929, s. 226.

${ }^{24}$ K. Zalewski, op. cit. s. 2.

${ }^{25}$ List do Johna Murraya, 23 sierpnia 1821, Byron's Letters and Journals, red. L.A. Marchand, t. 8, London 1978, s. 187; list do Lady Byron, 14 września 1821 roku; ibid., s. 210. Polski przekład „teatr wyobraźni” za Byron, Listy i pamiętniki, red. J. Żuławski, Warszawa 1960, s. 299. Określenie to Byron zastosował w odniesieniu do swoich tragedii historycznych pisanych w tym okresie, ale badacze są zgodni co do trafności terminu w stosunku do jego pozostałych utworów dramatycznych, a Alan Richardson w swojej książce A Mental Theater. Poetic Drama and Consciousness in the Romantic Age (University Park and London 1988) używa go do określenia angielskiego dramatu poetyckiego epoki romantyzmu. 
Zapomniałem panu donieść, że ukończyłem coś w rodzaju poematu dialogowanego (wierszem białym [dość niefortunne tłumaczenie angielskiego blank verse, nierymowanego pentametru jambicznego - M.C.]) czy też coś w rodzaju dramatu, którego wyciągiem jest czarodziejskie wywołanie duchów [błąd tłumacza; chodzi tu o wersy poematu, które zostały wcześniej opublikowane jako „Incantation” - zaklęcie - M.C.]. Zacząłem go w Szwajcarii przeszłego lata, jest on w trzech aktach w rodzaju dzikim, metafizycznym i niewytłomaczonym.

Wszystkie osoby oprócz dwóch czy trzech, są duchami ziemi, powietrza i wód; scena odbywa się w Alpach; bohater jest niby czarnoksiężnikiem, którego męczą wyrzuty sumienia, przyczyna ich zostaje w połowie niewyjaśniona. Błądzi tu i owdzie wywołując duchy, które mu się ukazują bez oddania mu żądanej przysługi; kończy wywołaniem ducha, który mu daje odpowiedź dwuznaczną), w akcie III-ciem służba znajduje go umierającym w wieży, gdzie zwykł był studiować swą sztukę.

Z tego szkicu widzi pan, że nie mam zbyt wielkiej opinii o sztuce; - lecz pociesza mnie to, żem uniemożliwił przedstawienie na scenie, gdyż moje stosunku[i] z „Drury Lane” zrodziły we mnie najwyższą odrazę do teatru ${ }^{26}$.

Chociaż Byron zarzeka się, że jego poemat nie nadaje się do wystawienia, wielu badaczy wskazuje na możliwość inspiracji teatralnych w jego kompozycji. Ani alpejska sceneria, ani duchy jako postacie sceniczne nie stanowiły istotnej przeszkody do inscenizacji teatralnej; wprost przeciwnie, często pojawiały się na scenie w angielskich teatrach na przełomie XVIII i XIX wieku ${ }^{27}$. Peter Cochran argumentuje, że sama rola Manfreda napisana była z myślą o wielkiej gwieździe ówczesnej sceny - podziwianym przez Byrona Edmundzie Keanie ${ }^{28}$.

Niezależnie od opinii samego Byrona utwór trafił na scenę londyńskiego teatru Covent Garden 29 października 1834 roku, dziesięć lat po śmierci poety w Missolonghi 19 kwietnia 1824 roku. Biorąc pod uwagę sensacyjną reputację poety oraz liczne teatralne adaptacje jego utworów poetyckich, zarówno w Wielkiej Brytanii, jak i na kontynencie europejskim, było to nieuniknione. Tradycją teatralną stało się odgrywanie ról bohaterów Byrona przez aktorów ucharakteryzowanych na poetę ${ }^{29}$. Standardowa opinia krytyczna, według której w swoich protagonistach Byron portretuje samego siebie, znalazła odbicie w praktyce teatralnej, co niewątpliwie było atrakcją dla spragnionej biograficznych skandalów publiczności. Do najlepszych odtwórców bohaterów poematów Byrona należał Edmund Kean, który występował jako Selim w scenicznej adaptacji Narzeczonej z Abydos (Dru-

${ }^{26}$ List cytuję za przekładem opublikowanym w notce $Z$ powodu Manfreda, „Kurier Poranny”, 14 marca 1892, r. 16, nr 74, s. 5, https://crispa.uw.edu.pl/object/files/133552/display/Default (dostęp: 25.10.2021). Moje adnotacje w tekście na podstawie porównania z tekstem angielskim w Byron's Letters and Journals, red. L.A. Marchand, t. 5, Cambridge, MA, 1976, s. 170.

27 P. Baines, E. Burns, The Playhouses of London, 1768-1821 [w:] Five Romantic Plays, red. P. Baines, E. Burns, Oxford 2000, s. xxxv-xxxvi.

${ }_{28}$ P. Cochran, Manfred. An Edition of Manuscripts and a Collection of Essays, Newcastle upon Tyne 2015, s. 1-7. Według Cochrana na możliwość wystawienia Manfreda na ówczesnej scenie wskazuje B. Reitz, Byron's Praise of Sheridan [w:] Byron as Reader, red. P. Bridzun, F.E. Pointner, Essen 1999, s. 2.

${ }_{29}$ P.J. Manning, Edmund Kean and Byron's Plays, „Keats-Shelley Journal”, 1972/1973, t. 21/22, s. 188-206, cyt. w: F. Burwick, Staging Manfred [w:] On the 200 Anniversary of Lord Byron's Manfred. A Collection of Commemorative Essays, red. O.F. Miranda, Romantic Circles, 2019, https://romanticcircles.org/praxis/manfred/praxis.2019.manfred.burwick.html (dostęp: 2.02.2021). 
ry Lane 5 lutego 1818 roku) i do tej tradycji sięgnął Henry Gaskell Denvil w roli Manfreda w inscenizacji Alfreda Bunna z muzyką Henry'ego Bishopa. Emfaza w tym przedstawieniu położona była na efekty wizualne, a dekoracje przedstawiające scenerię alpejską, zamek Manfreda oraz dwór Arymana wzorowany na obrazie Pandemonium Johna Martina przygotowane zostały przez rodzinę Grieve specjalizującą się w wykonywaniu scenografii teatralnych. Wykorzystano również liczne efekty specjalne. Afisze określały przedstawienie jako ,choralną tragedię" i faktycznie niemal w każdej scenie pojawiała się muzyka, chóry i balety, a tekst Byrona uległ znacznej modyfikacji ${ }^{30}$. Muzyka Henry’ego Bishopa wykorzystywała motywy z Carla Marii Webera ${ }^{31}$. W ten sposób poemat dramatyczny Byrona został przekształcony na modłę popularnych dziewiętnastowiecznych melodramatów.

Na kontynencie europejskim Manfred Byrona cieszył się szczególną popularnością w Niemczech. Zafascynował Roberta Schumanna, który jesienią 1848 roku zaadaptował poemat do wykonania w oprawie muzycznej, komponując uwerturę do Manfreda oraz ilustrację muzyczną ${ }^{32}$. Jak pokazała Laura Tunbridge, obszerny esej Karla Adolfa Suckowa, na którego przekładzie Schumann oparł się w swojej adaptacji, wywarł duży wpływ na myślenie kompozytora o poemacie. Suckow, z wykształcenia teolog, uważał, że utwór Byrona nadaje się na scenę. Wskazywał na potrzebę akompaniamentu muzycznego i przedstawiał liczne pomysły dotyczące inscenizacji, a szczególnie przekonującego ukazania elementów nadprzyrodzonych. Co więcej sugerował, że bohater Byrona jest zbawiony na modłę Fausta Goethego ${ }^{33}$.

Prawykonaniem uwertury do Manfreda dyrygował sam Schumann. Premiera scenicznej wersji poematu, w reżyserii Eduarda Genasta, z orkiestrą pod batutą Franza Liszta, odbyła się w Hoftheater w Weimarze 13 czerwca 1852 roku bez udziału kompozytora ${ }^{34}$. Wśród muzykologów toczyła się debata, o jakim wystawieniu myślał Schumann dla swojej kompozycji - czy miało to być odczytanie tekstu poematu w wykonaniu jednego aktora czy pełna wersja sceniczna. Tunbridge przekonująco pokazuje, że ilustracja muzyczna Schumanna skomponowana była z myślą o pełnej inscenizacji teatralnej ${ }^{35}$. W Niemczech, Stanach Zjednoczonych i Francji ukształtowały się dwie główne tradycje wykonania Manfreda Schumanna - jako wystawienie teatralne z pełną obsadą aktorską oraz w wykona-

${ }^{30}$ L. Tunbridge, Schumann's Manfred in the Mental Theatre, „Cambridge Opera Journal” 2003, t. 15 , nr 2, s. 158-159, doi:10.1017/S0954586703001678 (dostęp: 29.03.2021).

${ }^{31}$ Ibid., s. 158.

32 Ibid., s. 160.

33 Ibid., s. 161, 181.

${ }^{34}$ Według listu Liszta do Schumanna z 26 czerwca 1852 roku w roli Manfreda wystąpił pan Pötsch (Franz Liszt's Briefe, red. La Mara [I.M. Lipsius], t. 1, Leipzig 1893) s. 110-111, Google Books. Laura Tunbridge (s. 162) podaje Ernsta Possarta jako wykonawcę roli tytułowej, korygując Liszta; Possart figuruje również jako odtwórca roli tytułowej w bibliografii wersji scenicznych Manfreda opracowanej przez Petera Cochrana. Jednak w roku 1852 Possart miał zaledwie 11 lat, jest więc mało prawdopodobne, by wystąpił w tej roli.

${ }^{35}$ L. Tunbridge, op. cit., s. 159-162. 
niu jednego aktora ${ }^{36}$. W 1868 roku Ernst Possart zdobył rozgłos swoją rolą Manfreda na scenie w Monachium ${ }^{37}$. We Francji poemat Byrona w przekładzie Victora Wildera miał swoją premierę 13 marca 1886 roku w ramach koncertów orkiestry Colonne (Concerts Colonne) ze słynnym aktorem Comédie Française Jeanem Mounetem Sully jako odtwórcą całego tekstu. Występował w tej roli regularnie do 1909 roku $^{38}$. Kotarbiński powoływał się na oba te wykonania w swojej odpowiedzi na zarzuty Zalewskiego, a sukces obu aktorów był dla niego inspiracją.

\section{Manfred w Teatrze Wielkim: kampania promocyjna}

Polska premiera Manfreda Byrona z muzyką Schumanna odbyła się 12 marca 1892 roku na scenie Teatru Wielkiego. Przedstawienie przygotował Bolesław Ładnowski z dekoracjami Józefa Guranowskiego ${ }^{39}$. Chociaż Kotarbiński narzekał na negatywne nastawienie warszawskiego środowiska krytyki teatralnej, to jako znany literat i gospodarz salonu warszawskiego prowadzonego przez żonę Lucynę $e^{40}$ mógł także liczyć na wsparcie wielu krytyków dla swojego projektu. Premiera była więc poprzedzona swoistą kampanią promocyjną w warszawskich periodykach, w których regularnie informowano o przygotowaniach do spektaklu. W „Tygodniku Ilustrowanym” na miesiąc przed premierą, 13 lutego, ukazał się esej Marii Bardzkiej, Manfred i Faust, który omawiał interpretację obu utworów w eseju Georges Sand $O$ dramacie fantastycznym"41. W dniu premiery 12 marca na pierwszej stronie „Kuriera Codziennego” opublikowano fragment przekładu Gabriela Kempnera, a w „Przeglądzie Tygodniowym”, ukazał się esej o Manfredzie jego autorstwa ${ }^{42}$.

Kempner - z wykształcenia prawnik, znany jako literat, tłumacz oraz publicysta - pisał regularnie recenzje teatralne dla czasopisma Adama Wiślickiego. Był również odpowiedzialny za adaptację sceniczną Manfreda, chociaż ta niewiele odbiegała od wersji Schumanna. Jego wypowiedź można uznać za swoistą deklarację programową zespołu Ładnowski-Kotarbiński-Kempner, pracującego nad inscenizacją. Kempner podkreśla rangę Byrona w literaturze XIX wieku - widzi w nim poetę, który po klęsce ideałów rewolucji francuskiej i powrocie do społecznego i politycznego status quo jako jeden z nielicznych wyraża „opór ludzkości

${ }^{36} \mathrm{O}$ tradycji dwóch interpretacji w Niemczech, zob. A. Striker, Manfred in Concert. An American Premiere, „Bulletin of Research in the Humanities” 1982, nr 85, s. 479-488, cyt. w: L. Tunbridge, op. cit., s.159-160. Tunbridge pokazuje, że podobne konwencje pojawiały się w inscenizacjach w Wielkiej Brytanii, gdzie dominowały przedstawienia teatralne, i w Stanach Zjednoczonych, gdzie Edwin Booth recytował całość poematu; L. Tunbridge, op. cit., s. 159.

37 M. Geck, Robert Schumann: The Life and Work of a Romantic Composer, przeł. S. Spencer, Chicago 2012, s. 243.

${ }^{38}$ Manfred, THEATREONLINE.com, https://www.theatreonline.com/Spectacle/Manfred/43084 (dostęp 30.04.2021).

39 Z. Jasińska, op. cit., s. 38.

40 Zob. L. Kotarbińska, Wokół teatru. Moje wspomnienia, Warszawa 1939, s. 13-17, https://www. sbc.org.pl/dlibra/show-content/publication/edition/34364?id=34364 (dostęp 1.09.2021).

${ }^{41}$ M. Bardzka, Manfred i Faust, ,Tygodnik Ilustrowany” 1892, seria 5, t. 5, nr 111, s. 98-99.

42 G. Kempner, Byronowski Manfred, „Przegląd Tygodniowy” 1892, r. 27, nr 11, s. 133-134. 
przeciw tej reakcji, który całą siłą swego pierwszorzędnego natchnienia, gorąco czułego serca, walczy przeciw parafiańskiej hipokryzji, walącej się na głowę jego spółczesnych” Manfred jest zarazem „najsubiektywniejszym z subiektywnych dzieł jego twórcy, choć równie jednocześnie jak i inne, jest pieśnią natchnioną przez ogólne niedole ludzkości" ${ }^{43}$. To uniwersalistyczne odczytanie Manfreda przypomina cytowaną na początku tego artykułu interpretację Kotarbińskiego. Krytyk widzi genezę utworu w skandalu, który doprowadził do wyjazdu Byrona z Anglii. W odróżnieniu jednak od obecnych badaczy, a podobnie jak większość jemu współczesnych, widzi źródła wyjazdu poety z ojczyzny we wrogości establishmentu, który zantagonizował swoją satyrą, oraz w autokreacji Byrona jako „grzesznika”. Tu powtarza opinię Włodzimierza Spasowicza z rozprawy Byron i niektórzy jego poprzednicy ${ }^{44}$, której przedruk ukazał się w II tomie Pism, opublikowanym z początkiem 1892 roku. Bagatelizuje natomiast znaczenie skandalu z powodu rozpadu małżeństwa Byrona, oskarżając żonę poety o rozprzestrzenianie plotek o jego romansie z przyrodnią siostrą, Augustą Leigh ${ }^{45}$.

\section{Przedstawienie w Teatrze Wielkim}

Adaptacja Kempnera nie została wydana w formie książkowej, natomiast jej obszerne fragmenty zostały ogłoszone drukiem w czasopismach ${ }^{46}$. Kempner podkreślał, że tłumaczył $\mathrm{z}$ angielskiego oryginału ,z zachowaniem możliwym rytmiki angielskiej, zastosowanym mniej więcej do układu, w którym Manfreda grywają na scenach niemieckich, z muzyką Schumanna" ${ }^{47}$. Stąd struktura jego przekładu opiera się na niemieckim libretto, które dostosowane było do możliwo-

${ }^{43}$ Ibid., s. 133.

${ }^{44}$ W. Spasowicz, Byron i niektórzy jego poprzednicy [w:] Pisma, t. 2, Petersburg 1892, s. 69-202. O pozowaniu na ,wielkiego zbrodniarza” przez Byrona zob. s. 126.

${ }^{45}$ Źródło cierpienia Manfreda leży w utracie jego ukochanej siostry i już współcześni domyślali się, że modelem tej postaci mogła być przyrodnia siostra poety Augusta Leigh. W 1869 roku Harriet Beecher Stowe opublikowała artykuł The True Story of Lady Byron's Life w „The Atlantic Monthly," a w styczniu 1870 roku książkę Lady Byron Vindicated, w której ukazała romans poety z Augustą jako powód odejścia Annabelli od męża. Publikacje Beecher Stowe były źródłem skandalu, większość krytyków wystąpiła jednak w obronie reputacji Augusty Leigh, atakując Annabellę jako bezduszną żonę. Zob. M. Seymour, In Byron's Wake. The Turbulent Lives of Lord Byron's Wife and Daughter. Annabella Milbanke and Ada Lovelace, London 2018, s. 442-455.

${ }^{46}$ Akt I przekładu Gabriela Kempnera z zapowiedzią premiery w Teatrze Wielkim ukazał się 27 lutego w "Tygodniku Ilustrowanym” (1892, seria 5, t. 5, nr 113, s. 134-35); scena 2 Aktu II rozmowa z Królową Alp - w „Kurierze Codziennym” 12 marca 1892 (Fragment z „Manfreda” Byrona, „Kurier Codzienny” 1892, r. 28, nr 72, s. 1, https://polona.pl/item/kurjer-codzienny-r-28nr-72-12-marca-1892-dod-poranny,NDEzNjk5ODc/0/\#info:metadata (dostęp: 12.04.2021); scena 4 Aktu II 12 marca w „Echu Muzycznym, Teatralnym i Artystycznym” 1892, nr 441 (11), s. 122-124; akt III w „Niwie” 1 kwietnia (1892, r. 21, nr 7, s. 111-113). Nie zachował się egzemplarz teatralny spektaklu w Teatrze Wielkim, ale w Archiwum Teatru im. Juliusza Słowackiego w Krakowie istnieje tekst przekładu Gabriela Kempnera, który był wykorzystany w przedstawieniu krakowskim z 1904 roku. W „Tygodniku Ilustrowanym” oraz w „Biesiadzie Literackiej” zostały również opublikowane rysunki przedstawiające wybrane sceny ze spektaklu w Teatrze Wielkim.

${ }^{47}$ G. Kempner, op. cit., s. 134. 
ści ówczesnej sceny. W ślad za wersją Schumanna monologi Manfreda są w kilku miejscach znacznie skrócone, a niekiedy usunięte (taki los spotkał fragment ,The stars are forth..." (III. 4. 1-45), w którym Manfred medytuje nad pięknem nocy i biegiem historii, wspominając swoją wizytę w rzymskim Koloseum).

$\mathrm{W}$ warszawskim przedstawieniu częste zmiany scenerii $\mathrm{w}$ poemacie Byrona zostały zredukowane do czterech odsłon. Z przyczyn pragmatycznych, cały akt I dzieje się w Alpach, Manfred wygłasza więc swój początkowy nocny monolog nie w gotyckiej Sali, lecz na górskim szczycie, co zmienia charakter jego czuwania, które w poemacie wyraźnie przywołuje Fausta w jego gotyckiej izbie. Tak jak w utworze Byrona, w scenie 1 wezwane przez Manfreda duchy wszechświata nie ukazują się widzom, pojawia się tylko gwiazda i słychać śpiew, a potem głosy zza sceny. Liczba duchów zostaje zredukowana z siedmiu do czterech, co odpowiada liczbie czterech żywiołów, nie tłumaczy natomiast pojawienia się gwiazdy, która w poemacie może być interpretowana jako gwiazda przeznaczenia Manfreda. Właśnie Duch Siódmy, przedstawiający się jako władca tej gwiazdy (pod którą narodził się Manfred) w poemacie przybiera kształt pięknej kobiety, stąd jego brak w wersji scenicznej jest zaskakujący. Owo odejście od tekstu wskazywało wielu recenzentów. Gdy po zniknięciu Ducha Manfred pada zemdlony, cztery duchy odśpiewują zaklęcie/klątwę, które jest skondensowaną wersją tajemniczej Inkantacji z poematu. Według Władysława Bogusławskiego temu przekleństwu, chociaż odśpiewanemu przez dwa basy, brakowało muzycznej dramatyczności ${ }^{48}$. W scenie 2 Manfred budzi się o świcie, wygłasza monolog, po czym zostaje uratowany przed samobójczą śmiercią przez Strzelca Alpejskiego.

W akcie II cztery sceny poematu zredukowano do dwóch odsłon - pierwsza odbywała się przed chatką Strzelca, której w pobliżu - ze względów praktycznych - umieszczono wodospad. Reprezentacja wodospadu, w którego promieniach ukazuje się Królowa Alp „nie dorasta[ła] ani pomysłem, ani wykonaniem do świetnej wystawy innych aktów"49. Pani Noiretówna w roli Królowej Alp spotkała się z licznymi uwagami krytycznymi - Jellencie wydawała się „,banalną w tonie mowy"50, a Władysławowi Maleszewskiemu przypominała warszawską strojnisię, w opiętej sukience, ze stanikiem za krótkim na przodzie"51. Druga odsłona przedstawiała salę w pałacu Arymana, który zasiadał na tronie otoczony duchami. Ze szczególną pochwałą anonimowego recenzenta „Głosu” spotkała się scena spotkania Manfreda z duchem Astarte, w której Kotarbiński ,był natchnionym twórcą i artystą”: „Ani jednego krzyku, ani jednego ruchu ostrego - trup Astarty zdaje się być otoczonym jakimś zaklętym kołem, przez które przejść nie śmie nawet wola Manfreda. I mimo to słowa jego, stłumione i wpół otoczone mistyczną grozą dźwięczą tak przenikliwie, tak boleśnie - że czuje się jakąś pełnię

48 W. Bogusławski, Felieton Teatralny. ,Manfred” Byrona z muzyka Schumanna, „Gazeta Polska” 1892, nr 60 , s. 2.

49 (.), Z teatru. Manfred, „Kurier Poranny” 1892, r. 16, nr 73, s. 5.

${ }^{50}$ C. Jellenta [Napoleon Hirszband], ,,Manfred” na scenie naszej, „Prawda” 1892, nr 13, s. 151.

${ }^{51}$ Sęp [Władysław Maleszewski], Z Warszawy, „Biesiada Literacka” 1892, t. 33, nr 12, s. 177-178. Nazwiska autorów używających pseudonimów próbowałam ustalić na podstawie Stownika pseudonimów pisarzy polskich XV w. - 1970 r., t. 1-4, red. E. Jankowski, Wrocław 1994-1996. 
tragizmu"52. Zdaniem większości recenzentów niezgodne z muzyką wykonanie słów Astarte przez Helenę Marcello było chybione ${ }^{53}$, chociaż entuzjastyczny recenzent „Głosu” twierdził, że aktorka w roli Astarte „umiała [...] zamieścić cały swój talent w kilkunastu wyrazach" ${ }^{54}$.

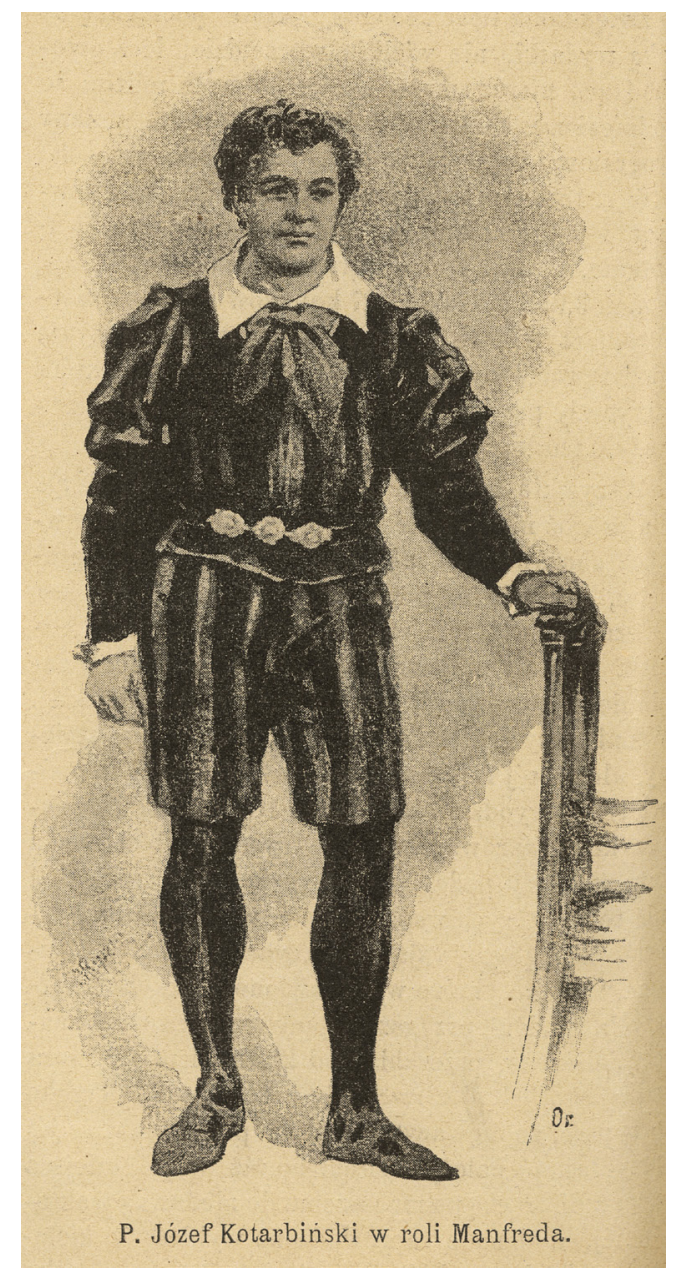

1. Józef Kotarbiński w roli Manfreda, rys. Józef Reszkiewicz, „Tygodnik Ilustrowany”, seria 5, t. 5, nr 116, s. 188.

52 a.p [Antoni Potocki?] Glosy, „Głos”, 19 marca 1892, r. 7, nr 12, s. 139, https://polona.pl/item/ glos-tygodnik-literacko-spoleczno-polityczny-r-7-nr-12-19-marca-1892,MTUyNTkwOTc/0/\#info: metadata (dostęp: 29.04.2021).

53 A. Rajchman, Manfred. Poemat dramatyczny lorda Byrona, „Echo Muzyczne, Teatralne i Artystyczne” 1892, nr 442, s. 139; K. Zalewski, Z teatru, „Kurier Warszawski” 1892, nr 75, s. 3.

${ }^{54}$ a.p. [Antoni Potocki?], op. cit., s. 139. 


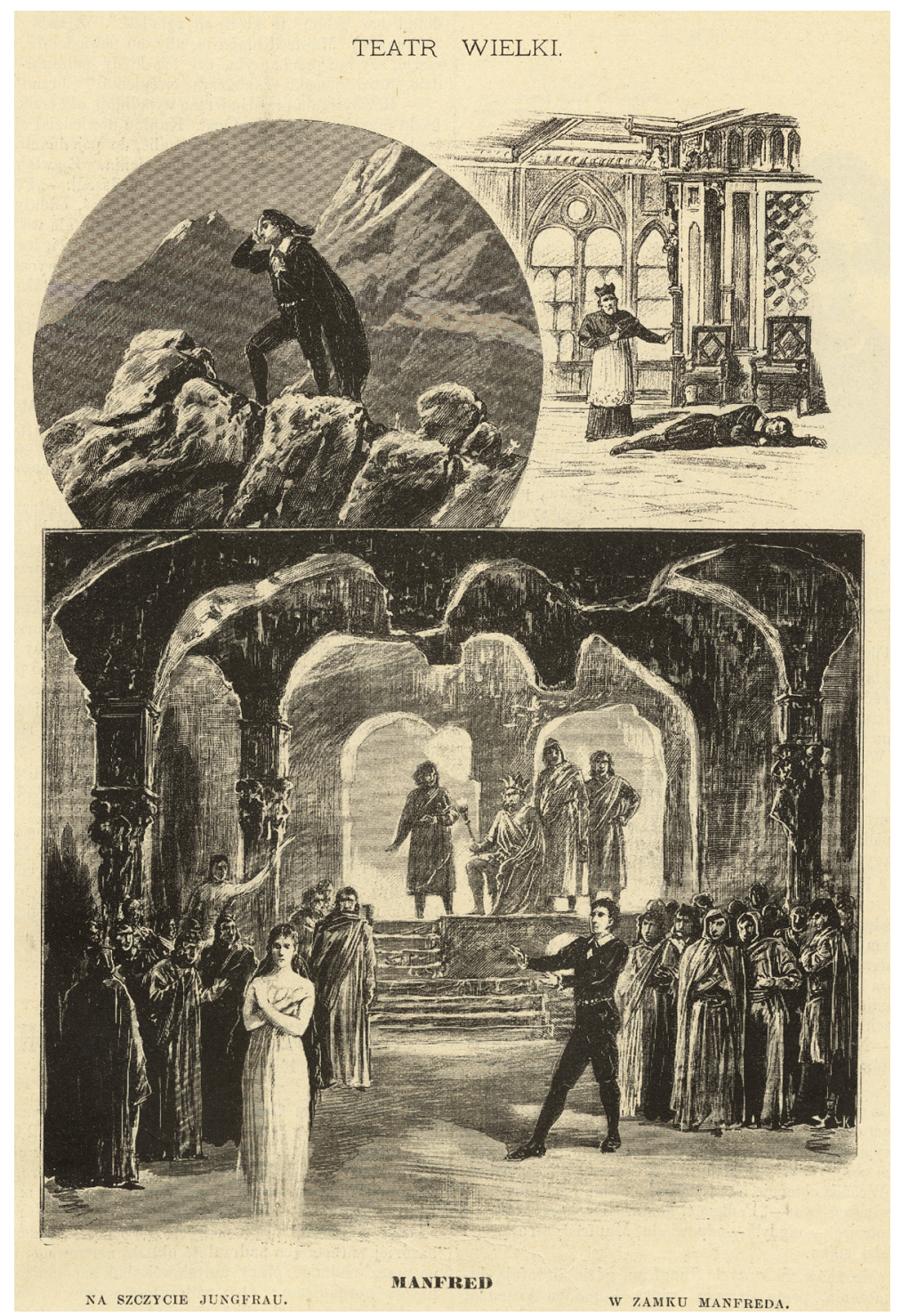

2. Manfred na scenie warszawskiej: Na szczycie Jungfrau. W zamku Manfreda. W państwie podziemnem Arimana. „Biesiada Literacka” 1892, t. 33, nr 14, s. 217. [Tytuły podaję za spisem treści czasopisma. Nazwisko autora rysunków nie jest podane].

Akt III lokuje akcję w całości w komnacie zamku Manfreda „ze świetnymi złudzeniami perspektywy"55 i otwiera się sceną 3 poematu, w której Manuel opowiada Hermanowi o tajemniczej historii Manfreda. Bolesław Ładnowski był powszechnie chwalony za rolę Opata, a przedstawienie duchów, które przychodzą po duszę Manfreda, spotkało się nawet z pochwałą Bolesława Prusa: ,To nie nasze 
poczciwe diabły, które lada chłop okpił, to - szaleństwo, strach, rozpacz... ohydne choroby duszy"; nie podobało się mu jednak, że ,zamiast wyłazić z różnych kątów, jak oprawcy polujący na swoją ofiarę, wyjeżdżają spod ziemi, podobni do wielu butelek ustawionych w oknie dystylarni" "56. Schumann zmodyfikował scenę śmierci Manfreda, wprowadzając chór śpiewający z oddali, jakby miały być to głosy dochodzące z pobliskiego klasztoru, „Et lux aeterna / Luccat eis!”. To wraz z powtórzeniem na końcu inscenizacji muzycznego motywu, który towarzyszył pojawieniu się Astarte w akcie II z równoczesną zmianą tonacji muzyki $\mathrm{z}$ mollowej na durową - sugeruje, jak pokazała Tunbridge, zbawienie Manfreda ${ }^{57}$. Żaden z recenzentów warszawskiego przedstawienia nie odczytywał jednak explicite sceny śmierci Manfreda jako wskazującej na możliwość jego odkupienia. Uderzająca jest rozbieżność opinii w kwestii końcowej pieśni chóru, przy której kona Manfred. Bogusławski uważał ją za ,jedyny [...] błysk światła w tym obrazie o ciemnym, pesymistycznym kolorycie, w którym muzyk prześciga prawie poetę" i przywodziła mu na myśl zakończenie Fausta Schumanna ${ }^{58}$. Ten komentarz zdaje się sugerować aprobatę krytyka wobec możliwości chrześcijańskiego odczytania poematu. Aleksander Poliński natomiast uważał, że „kompozycja ta [...] jest zupełnie zbyteczną i niepotrzebnie głuszącą ostatnie słowa umierającego Manfreda"59.

W przedstawieniu, obok Kotarbińskiego i Ładnowskiego, wystąpili: z aktorek Rakiewiczowa (Nemezys), Marcellówna (Astarte), Noiretówna (Królowa Alp), z aktorów Narkiewicz, Nowicki, Trapszo, Hozman, Waliszewski, Borawski i Bolesławski ${ }^{60}$. Ilustracja muzyczna, która składała się z, ,z uwertury i 15 numerów muzycznych, jako to: kwartetów i chórów mieszanych" wykonana była przez solistów oraz chóry mieszane i orkiestrę Teatru Wielkiego pod kierunkiem Michała Hertza $^{61}$. Kwartet basów wykonywali Niedźwiecki, Crotti, Siwicki i Rutkowski; kwartet na głosy mieszane Wojakowska, Babińska, Kwieciński i Niedźwiecki ${ }^{62}$.

W recenzjach przedstawienia w pierwszej kolejności opisywano scenografię. Szczególnie chwalono specjalnie przygotowaną do tego spektaklu dekorację w akcie I: „Alpejska okolica ze skalistymi szczytami Jungfrau i lodowcami, płonącymi w blaskach wschodzącego słońca, po zniknięciu porannych mgieł, jest prawdziwym arcydziełem w swoim rodzaju i świadczy o wysokiej artystycznej technice p. Guranowskiego, z pod którego pędzla wyszła"63.

${ }_{56}$ B. Prus, Kronika tygodniowa (Awantura z powodu Manfreda), „Kurier Codzienny” 1892, r. 28, nr 85, s. 1. Przedruk w: B. Prus, Kroniki, red. Z. Szweykowski, t. 13, Warszawa 1963, s. 187. Wszystkie cytaty z wydania Szweykowskiego.

${ }^{57}$ L. Tunbridge, op. cit., s. 174-183.

${ }^{58}$ W. Bogusławski, op. cit., s. 2.

${ }_{59}$ A. Poliński, ,Manfred” [rec. muzyki], Z teatru, „Kurier Poranny”, 1892, r. 16, nr 71, s. 5, https://crispa.uw.edu.pl/object/files/133555/display/Default (dostęp: 25.10.2021).

${ }^{60}$ (.) Z teatru. ,, Manfred”, s. 4.

${ }^{61}$ Ibid., s. 4.

${ }^{62} Z$ teatru, „Kurier Poranny”, 1892, r. 16, nr 37, s. 3, https://crispa.uw.edu.pl/object/files/133577/ display/Default (dostęp: 25.10.2021).

${ }^{63}$ (.) Z teatru. Manfred..., s. 5 . 
Większość komentatorów pochlebnie pisała o kreacji Manfreda przez Kotarbińskiego. Kontynuując tradycję sceniczną, ucharakteryzowany był na Byrona na podstawie popularnych w XIX wieku rycin, głównie tych opartych na portrecie George'a Sandersa ${ }^{64}$. Z recenzentów jedynie Zalewski wyrażał się o tej decyzji krytycznie, sugerując, że zachęca do biograficznego odczytania poematu (a więc w domyśle do podkreślenia pogłosek o kazirodztwie), choć sam sugerował genezę poematu w życiu poety.

Jego zdaniem Manfred powinien być przedstawiony z czarnym, lekko oszronionym zarostem jako , mąż [..] w pełnym rozwoju męskiej siły i wieku" ${ }^{65}$. Z kolei Jellenta, ewidentnie mając na myśli zastrzeżenia Zalewskiego, do którego ataku na przedstawienie odnosi się otwarcie w swojej recenzji, domagał się ,więcej szparkiej młodości w Manfredzie”, komplementując kreację Kotarbińskiego: „Possartowi z Monachium w ogóle nie ustępuje, a miejscami go przerasta”66. Według recenzenta „Gazety Warszawskiej”, ,,artysta za mało uwzględnia w charakterze bajronowskiego bohatera pierwiastek siły, nieugiętej woli i dumy, a za wiele kładzie nacisk na sentymentalizm i marzycielstwo". Mimo to Kotarbiński stworzył pamiętną kreację; chwalony był przede wszystkim za swoją deklamację: ,,artysta akcentował świetnie całą skalę uczuć, miotających zbolałą duszę bohatera, począwszy od szeptu rezygnacji, a skończywszy na okrzyku wściekłego gniewu i oburzenia. Gra właściwa nie pozostawiała też nic do życzenia; zwłaszcza w chwilach dramatyczniejszych porwał artysta widzów potęgą prawdziwego uczucia" ${ }^{67}$. Co do gry reszty aktorów, zdania krytyków były podzielone. Przykładowo w „Biesiadzie Literackiej” w pochlebnym dla przedstawienia artykule pisano, że ,grają swe role kilkuminutowe z takim przejęciem się, jakby od tego sława ich zależała"68. Natomiast zdaniem recenzenta "Głosu” występowali tylko jako „figuranci”, którzy „ustępują [...] świetnej maszynerii i akcesoriom martwym”ø9.

\section{Spory krytyczne wokół warszawskiego przedstawienia}

Recenzje przedstawienia odzwierciedlają mieszane reakcje krytyków i publiczności. Większość można podzielić na pochlebne lub krytyczne w zależności od gustów estetycznych i układów towarzyskich redakcji czasopism. Przeciwnicy wprowadzenia do repertuaru Teatru Wielkiego poematu dramatycznego Byrona wypowiadali się głównie na łamach „Kuriera Warszawskiego” i „,Wieku”, zasadniczo rozwijając wcześniejsze zastrzeżenia Zalewskiego wobec pomysłu wprowa-

${ }^{64}$ O portrecie autorstwa Sandersa i popularności tego wizerunku Byrona, zob. G. Bond, C. Kenyon-Jones, Dangerous to Show. Byron and His Portraits, London 2020, s. 27-31. Rycina Byrona oparta na tym portrecie została opublikowana w licznych czasopismach jako ilustracja recenzji lub fragmentów poematu, np. w „Tygodniku Ilustrowanym” 1892, seria 5, t. 5, nr 113, s. 134, w „Biesiadzie Literackiej” 1892, nr 14, s. 218 i w „Kurierze Codziennym” 1892, nr 72, s.1.

${ }^{65}$ K. Zalewski, Z teatru..., s. 2.

${ }^{66}$ C. Jellenta, op. cit., s. 151.

${ }^{67}$ P., Teatr (Manfred), „Gazeta Warszawska” 1892, r. 119, nr 69, s. 1.

${ }^{68}$ Bajron w życiu i na scenie, ,Biesiada Literacka” 1892, nr 14, s. 218.

69 a.p. [Antoni Potocki?], op. cit., s. 139. 
dzenia Manfreda na scenę i podkreślając niezrozumiałość opinii „filozoficznych” w poemacie dla przeciętnego widza. Obrońcy przedsięwzięcia występowali między innymi na łamach „Gazety Polskiej”, „Przeglądu Tygodniowego,” "Słowa,” „Głosu” i „Prawdy”. Spory o Manfreda nie ograniczały się do polemiki między poszczególnymi czasopismami, ale ewidentnie miały miejsce również $\mathrm{w}$ ich redakcjach. Dobrym tego przykładem jest „Tygodnik Ilustrowany” z 19 marca 1892 roku, gdzie zamieszczono dwie różne recenzje przedstawienia. Edward Lubowski, dramaturg i krytyk związany z ruchem pozytywistycznym, którego dramat obyczajowy Bawidetko wystawiany był w tym okresie na scenie Teatru Rozmaitości, kwestionował sens wystawiania Manfreda, podkreślając zapotrzebowanie na aktualne sztuki teatralne ${ }^{70}$. Jednocześnie w swojej stałej rubryce ,Z tygodnia na tydzień" Marian Gawalewicz, krytyk i człowiek teatru, wystąpił w obronie przedstawienia, twierdząc, że wzbudziło entuzjazm publiczności na balkonach ${ }^{71}$.

Zalewski rozwinął swój wcześniejszy argument o niesceniczności poematu w obszernym artykule w „Kurierze Warszawskim”, podkreślając trudności w zrozumieniu Manfreda przez przeciętnych widzów teatralnych. Tym razem jednak nie pisze o poemacie jako nieaktualnym ,zabytku pierwocin romantyzmu”, lecz po swojej pomyłce sprzed roku popisuje się znajomością utworu i podkreśla swój podziw dla Byrona. Głównym argumentem Zalewskiego przeciwko inscenizacji teatralnej jest brak akcji dramatycznej w Manfredzie. Przedstawieniu zarzuca, że konieczność przystosowania tekstu do potrzeb sceny i ilustracji muzycznej prowadzi do licznych skróceń, a użyte dekoracje zmieniają scenerię dramatu - zamiast w galerii gotyckiej zaczyna się na szczytach Alp, ,wieszczka gór pojawia się przy chatce strzelca alpejskiego, a biedny Manfred nie może nawet umrzeć" na wieży, gdzie zwykł spędzać czas z ukochaną Astarte. W rezultacie „zostaje [...] długi monolog dla jednego artysty, który przy najwyższych wysiłkach sztuki deklamacyjnej urozmaicić go nie jest w stanie" ${ }^{\text {"72 }}$. Podobną argumentację przedstawił w „Wieku”, dzienniku redagowanym przez Zalewskiego, Antoni Mieszkowski ${ }^{73}$. W tym samym numerze Zygmunt Noskowski krytycznie ocenił muzykę Schumanna do Manfreda, chwaląc jednak wykonanie orkiestry Michała Hertza ${ }^{74}$.

Z kolei Józef Kenig i Władysław Bogusławski podkreślali zasługę Kotarbińskiego we wprowadzeniu na scenę wielkiej poezji. Kenig w „Słowie” chwalił odwagę kierownictwa artystycznego Teatru Wielkiego za podjęcie decyzji o wystawieniu Manfreda, a w spektaklu widział ,silne na rzecz poezji wystąpienie, rodzaj protestacji przeciw rozpanoszeniu się cynicznego materializmu" "75 $i$ odpowiedź na

${ }^{70}$ E. Lubowski, „Manfred” dramat w 4-ch aktach Byrona, muzyka Roberta Schumanna. Z oryginatu przetozyt $i$ do sceny przystosowat Gabryel Kempner. Przeglad teatralny, ,Tygodnik Ilustrowany" 1892, nr 116, seria 5, t. 5, s. 182.

${ }^{71}$ M.G. [Marian Gawalewicz], Z tygodnia na tydzień, „Tygodnik Ilustrowany” 1892, seria 5, t. 5 , nr 116 .

${ }^{72}$ K. Zalewski, Z teatru..., s. 2.

${ }^{73}$ M. [Antoni Mieszkowski], Przeglad teatralny, „Wiek”, 1892, r. 20, nr 58, s. 3, https://crispa. uw.edu.pl/object/files/251401/display/PDF (dostęp: 29.04.2021).

${ }^{74}$ Z. Noskowski, Muzyka w „Manfredzie”, Przeglad teatralny, „Wiek” 1892, r. 20, nr 58, s. 3 , https://crispa.uw.edu.pl/object/files/251401/display/PDF (dostęp: 29.04.2021).

75 J. Kenig, Z teatru, „Słowo” 1892, r. 11, nr 69, s. 2. 
„,naturalizm” dominujący na scenie. Bogusławski w swojej recenzji w „Gazecie Polskiej” argumentował, że poezja Byrona ze swoim bólem istnienia i subiektywizmem była w pełni aktualna i wpisywała się w nowe trendy epoki:

Słyszę naokoło, że się Byron zestarzał, - patrzę na „Manfreda” i pytam się w czem: czy w duchu, czy w formie? Jest wielkim, największym może poetą indywidualizmu; więc cóż go oddala od modernistów, stawiających indywidualizmowi apoteozy? Jest zwiastunem pesymizmu, więc z jakiej racji pokolenia szoppenhauerzystów mają przez ramię spoglądać na twórcę „Kaina”, tragedii tego, co jest typowo tragicznym w egzystencji człowieka rodzącego się po to, żeby cierpić, błądzić i umrzeć? ${ }^{76}$

Zdaniem Bogusławskiego, mimo braku dramatyczności poematu Byrona, połączenie imponującej scenografii, muzyki Schumanna i potęgi słowa zrobiło ogromne wrażenie na premierowej publiczności ${ }^{77}$. Przedstawienie Manfreda w Teatrze Wielkim było również punktem wyjścia do rozważań Bogusławskiego nad znaczeniem momentów lirycznych w dramacie w artykule Poezja $w$ teatrze w „Bibliotece Warszawskiej”. Tu Bogusławski przeciwstawia się zwolennikom „,ewolucji” w teatrze, wskazując na uniwersalność uczucia i poezji: „Manfred! Alboż go nie znamy, alboż był nam choć przez chwilę obcym, alboż naprawdę rozłączyliśmy się z nim kiedy! Alboż przestaliśmy na jeden moment rozumieć i odczuwać jego wzruszenia?" W monologach Manfreda krytyk słyszy słowa Słowackiego i Mickiewicza oraz podkreśla ponadczasowość tej poezji ${ }^{78}$.

Aktualność Manfreda dla młodej generacji, z której wywodzili się twórcy Młodej Polski, podkreślona została przez również Jellentę, który pisze o potężnej sile poematu, mimo wszystkich jego słabości. Poezja Byrona „chwyta słuchacza za gardło, za pierś - potęgą elementarnego czucia i chcenia, zuchwalstwem wyobraźni i roszczeń"79. Znacząca jest frazeologia młodopolska w tej wypowiedzi krytyka - w muzyce Schumanna, współautor Forpoczt (1895) widzi „ciche, bezdenne skupienie [...], rozdzierający ból w niektórych chórach, w uwerturze melancholię powolnego zamierania przy wtórze chrapliwych dąsów szatana" ${ }^{\text {" }}$.

Do debaty dołączył również Bolesław Prus w swojej stałej rubryce „Kronika tygodniowa” w „Kurierze Codziennym”. Wanda Krajewska odczytała jego artykuł jako krytykę bohatera byronicznego ${ }^{81}$ i przeważnie tak samo interpretują go badacze twórczości Prusa ${ }^{82}$. Trudno nie zgodzić się z ich opinią, można jednak dostrzec pewną ambiwalencję autora Lalki wobec tego przedstawienia. Obiektem satyry jest nie tylko Manfred i jego zmagania z duchami, lecz również recenzenci teatralni, a przede wszystkim kolega redakcyjny Prusa, Adam Breza, oraz prze-

${ }^{76}$ W. Bogusławski, Felieton teatralny..., s. 2.

77 Ibid., s. 2.

78 W. Bogusławski, Poezja w teatrze, „Biblioteka Warszawska” 1892, t. 2, s. 298. O głębokim przywiązaniu Bogusławskiego do tradycji romantycznej zob. T. Sobieraj, Polska krytyka i myśl teatralna w drugiej połowie XIX wieku. Studia i szkice, Kraków 2014, s. 25: „Romantyczny kult poezji, związany ze stylem odbioru nastawionym na poszukiwanie doznań wzniosłych i uszlachetniających czytelnika lub widza, tworzył podwaliny systemu estetycznego Bogusławskiego".

${ }^{79}$ C. Jellenta, op. cit., s. 151.

${ }^{80}$ Ibid.

${ }^{81}$ W. Krajewska, op. cit., s. 60.

${ }^{82}$ Zob. np. Z. Szweykowski, Twórczość Bolesława Prusa, Warszawa 1972, s. 329. 
ciętny czytelnik, który Manfreda nie rozumie. Humorystyczny felieton napisany został w formie dialogu: listu fikcyjnego typowego prenumeratora, który czyta publikacje firmy Gebethner i Wolff, ,w celu ukształcenia umysłu i uszlachetnienia serca", skonfundowanego recenzjami po obejrzeniu przedstawienia poematu dramatycznego Byrona w Teatrze Wielkim oraz odpowiedzi persony Prusa w imieniu wydawnictwa ${ }^{83}$. Autor listu przedstawia się jako człowiek interesów oraz „przeciętny” czytelnik obu „Kurierów” (Porannego i Codziennego) i „Tygodnika Ilustrowanego" (czyli czasopism wydawanych przez Gebethnera i Wolffa) oraz „,zwykły konsument widowisk teatralnych”, gustujący w dramatach mieszczańskich, komediach i farsach, takich jak wystawiane wówczas w Teatrze Nowym Dom wariatów Wilhelma Jacoby'ego i Carla Laufsa ${ }^{84}$.

Do pójścia na Manfreda jako na spektakl „,z muzyczką i bardzo pięknymi dekoracjami" zachęciła go szwagierka studiująca w konserwatorium ${ }^{85}$. Dekoracje i duchy bardzo mu się podobały, ale nie jest w stanie zrozumieć, o co chodzi w przedstawieniu:

Bo powiedzieć, że: łatwo się umiera - to rzecz wiadoma; a choćby komu i trudno się umierało - nie poradzi. Zaś pokazać duchy, a właściwie przeciągnąć je tylko widzowi pod nosem, to znowu trochę za mało.

Mimo to wszystko przedstawienie wabi człowieka i chętnie by popatrzył na te góry, wschód słońca, wodospad i na tę całą gromadę duchów, gdyby choć... cokolwiek to rozumiał.

By zrozumieć sens przedstawienia czytelnik sięga po recenzje: „Czytam - jeden pan mówi, że Manfred nie dla takich jak ja, a drugi - że Manfreda tacy jak ja nie zrozumieją, więc nie trzeba go pokazywać" ${ }^{\prime 6}$. Stereotypowe stwierdzenia recenzentów, takie jak „Manfred to walka ducha z niemożebnością odgadnięcia całej prawdy - to najgłębszy i najbardziej ciemny jęk bajronizmu..." wzruszają jego żonę i jej siostrę do łez, ale dla niego są niezrozumiałe. Kobiety ewidentnie uwielbiają Byrona, działa na ich wyobraźnię zakazana autodestrukcyjna miłość.

Prus kieruje swoją satyrę przede wszystkim na recenzję Brezy, który w tym samym „Kurierze Codziennym”, gdzie ukazywała się „Kronika tygodniowa”, w dzień po premierze, 13 marca, stwierdził, że nie ma sensu pisanie o Manfredzie w obecnych czasach, gdyż na ten temat napisano już zbyt wiele, a , [k]to z czytelników lub widzów o tym wszystkim nie wie, tego pouczyć nie może dziennikarski artykuł - więcej powiem: tego Manfred nie jest w stanie zająć - i powiem jeszcze więcej: tego musi znużyć" ${ }^{87}$. Przyjemność i zaintrygowanie fikcyjnego prenumeratora przedstawieniem, którego nie rozumie, zadają kłam opinii Brezy.

Czytelnik, choć nieoczytany w poezji romantycznej i krytyce, która raz po raz publikowana była na łamach bardziej ambitnych czasopism, zasługuje na wyjaś-

${ }^{83}$ B. Prus, Kronika tygodniowa ..., s. 1. Przedruk w: B. Prus, Kroniki..., s. 180-187.

8414 marca „Kurier Poranny” oznajmiał, że „Wyborny Dom wariatów, który co przedstawienie zapełnia Teatr Mały po brzegi”, zejdzie wkrótce z repertuaru: $Z$ teatru. „Kurier Poranny” 1892, r. 16, nr 74, s. 3.

${ }^{85}$ B. Prus, Kroniki..., s. 180.

${ }^{86}$ Ibid., s. 181.

${ }^{87}$ A. Br. [Adam Breza], Manfred, „Kurier Codzienny” 1892, r. 28, nr 73, s. 1. 
nienie. Odpowiedź, której udziela narrator Prusa, jest żartobliwa i ironiczna. Zachowanie Manfreda zostaje najpierw ocenione ze zdroworozsądkowej perspektywy, oczywistej dla człowieka interesu. Samotnie ślęcząc nad księgami, ten młody człowiek prowadził zgubny tryb życia; co więcej, sam siebie opisuje jako maga, czego obecnym odpowiednikiem jest ,medium spirytystyczne”. „Pomimo jednak osobistych zapewnień o swojej nadziemskiej potędze (o czym co do samych siebie zapewniają dzisiejsze media) - Manfred robił bardzo niewiele, prawie nic. Tyle, że wałęsał się po wertepach i wywoływał moce nadziemskie, tylko... we własnej wyobraźni; w rzeczywistości zaś - mocno blagował"88. Prus przeciwstawia Manfreda współczesnym czarodziejom - chemikom i fizykom, którzy w Muzeum Przemysłu i Rolnictwa potrafią dokonywać prawdziwych cudów w swych eksperymentach.

Byron powinien być jednak atrakcyjny dla ,przeciętnego człowieka”, ponieważ ukazuje próbę zrozumienia tajemnic wszechświata, o których ten nie ma pojęcia, oraz zmagania z ,potęgami wyższymi”, a z nich składa się historia ludzkości. ,Jeżeli dodamy jeszcze: miłość - wybuchy dumy - odwagę, a nade wszystko styl, cudowny styl, tak obrazowy, że służy za instrukcję dla prześlicznych dekoracji, to będziemy mieli dostateczną liczbę przyczyn, tłumaczących wrażenie, jakie wywołuje Manfred" ${ }^{\prime 99}$. Ton Prusa jest prześmiewczy - Manfred ze swoją wizją świata opartą na magii nie ma pojęcia o prawdziwej wiedzy i nie rozumie sił nadprzyrodzonych, które bada współczesna nauka. Jednocześnie zmagania Manfreda ilustrują odwieczne pragnienie człowieka zmierzenia się z sekretami wszechświata i pasjami własnego serca, a te tematy były autorowi Lalki bliskie. Wystarczy przywołać postacie Wokulskiego i Geista.

O co faktycznie chodziło w krytycznej debacie o Manfredzie? Czy było to starcie pomiędzy kolejnymi pokoleniami, dyskusja o miejscu poezji na scenie czy raczej - jak pisał X. w „Przeglądzie Tygodniowym” - ,godziłoby się chociaż o tym pamiętać, że nie żadni pozytywiści, naturaliści i ewolucjoniści oponowali przeciw wystawieniu [...] Manfreda - ale znani nam fabrykanci sztuk teatralnych w łatwym do zrozumienia interesie własnym"90. Faktycznie głównymi oponentami wprowadzenia Manfreda na warszawską scenę byli popularni dramaturdzy, tacy jak Zalewski i Lubowski. Poniekąd mieli rację, twierdząc, że utwór Byrona ze swoją sukcesją długich monologów przerywanych scenami spotkań z duchami, istotami nadprzyrodzonymi i ludźmi nie ma walorów dramatycznych.

W obronie przedstawienia występowali przede wszystkim miłośnicy poezji romantycznej. Okazuje się, że było ich sporo wśród warszawskich krytyków teatralnych - zarówno tych niepowiązanych z żadną formacją literacką, takich jak Władysław Bogusławski, jak i zwolenników nowych trendów kulturowych, takich jak Cezary Jellenta. Ich nacisk na aktualność problematyki Manfreda buntu przeciw normom społecznym oraz gloryfikacji subiektywizmu i autonomii jednostki oraz, nade wszystko, bólu istnienia - wskazuje, że wybór repertuarowy kierownictwa Teatru Wielkiego odpowiadał duchowi czasów przełomu kulturo-

\footnotetext{
88 B. Prus, Kroniki..., s. 183-184.

89 Ibid., s. 186.

90 X. [Adam Wiślicki?], „Przegląd Tygodniowy” 1892, r. 27, nr 24, s. 287.
} 
wego. W roku 1895 Antoni Lange pisał w swoim wierszu Spowiedź dedykowanym Janowi Kasprowiczowi:

Błądzą po ziemi wiecznych cierpień syny -
Z sercem na dwoje rozdartem - Manfredzi -
Duchy z edeńskiej wygnane krainy.
A każdy w własne zapatrzon głębiny,
Samego siebie boleśnie rozważa
I sądzi myśli swe, żądze i czyny,
I sądem cierpień - cierpienia pomnaża
I klęczy u swych cierpień strasznego ołtarza ${ }^{91}$.

Określając młode pokolenie mianem „Manfredów”, Lange nawiązuje nie tylko do protagonisty Byrona, lecz również do Przygotowania w Kordianie, gdzie Szatan stwierdza: „Po szwajcarskich się górach nie snują Manfredy” i nakazuje Mefistofelowi obłąkać ,jakiegoś żołnierza” (w. 113; 115) ${ }^{92}$. Lange, jak gdyby na przekór Słowackiemu, który chce zadeklarować autonomiczność swojego protagonisty od bohatera Byrona, widzi wcielenia Manfreda u sobie współczesnych, równocześnie kwestionując zasadność próby Słowackiego odcięcia się od prototypów byronowskich. W tym kontekście określenie nowej epoki jako neoromantyzm, propagowane przez Edwarda Porębowicza ${ }^{93}$, autora opublikowanego w 1885 roku przekładu Don Juana Byrona, a ugruntowane przez Juliana Krzyżanowskiego w Neoromantyzmie polskim wydaje się w pełni adekwatne. Sama zaś decyzja o wystawieniu Manfreda przez Kotarbińskiego i Ładnowskiego jawi się jako wyraz ducha epoki, a debata wokół przedstawienia może być uznana za spór o miejsce dramatu poetyckiego na scenie i znaczenie romantyzmu u schyłku XIX wieku.

Manfred Byrona nie osiągnął sukcesu finansowego na warszawskiej scenie, mimo że był entuzjastycznie przyjęty przynajmniej przez część premierowej publiczności. Jeszcze gorzej potoczyły się jego losy w Krakowie, gdzie został wystawiony tylko raz - 16 maja 1904 roku - na benefis Michała Przybyłowicza, gdyż, jak wspomina Kotarbiński, sam był „,gotowy w głównej roli”, ale „,pod względem artystycznym pośpiesznie wystawione przedstawienie nie wypadło szczęśliwie"94. Myślę, że mimo rozczarowania finalnym brakiem sukcesu u publiczności dla Kotarbińskiego warszawskie przedstawienie Manfreda było ważnym eksperymentem teatralnym. Dzięki temu doświadczeniu nauczył się, na czym ma się skoncentrować w inscenizacjach wielkich polskich dramatów romantycznych tradycyjnie uważanych za niesceniczne, takich jak Kordian w Teatrze Miejskim w Krakowie, którego był dyrektorem w latach 1899-1905. Pisząc o swoim opracowaniu tekstu Kordiana na scenę i o konieczności wyeksponowania elementów dramatycznych utworu, ewidentnie myślał o warszawskim wystawieniu poematu Byrona:

91 A. Lange, Poezje, część II, Kraków 1898, s. 127.

92 J. Słowacki, Kordian [w:] Dzieła wybrane, t. 3: Dramaty, red. E. Sawrymowicz, Wrocław 1974, s. 99.

${ }^{93}$ E. Porębowicz propagował użycie terminu „neoromantyzm” dla określenia nowych trendów w literaturze w swojej pracy Polska poezja nowego stulecia (1902). Zob. A. Hutnikiewicz, op. cit., s. 26.

94 J. Kotarbiński, W stużbie sztuki i poezji, Warszawa 1929, s. 215. 
Scena ma ogromne znaczenie dla popularyzacji wielkich arcydzieł, narzuca ich piękno nawet słuchaczom niekulturalnym. W całości jednak poematy dramatyczne mogą być wystawione chyba na nieznającym ograniczeń teatrze wyobraźni. Przy opracowaniu tekstu na scenę należy wydobyć przede wszystkim wartości dramatyczne teatralne, momenty żywej akcji, dosadną psychikę figur, konflikty uczuć i namiętności. Doświadczenie lat ostatnich uczy, że nie należy teatrowi narzucać dzieł nie mających w sobie tętna dramatycznego, albowiem w próbach tego rodzaju rezultat nie odpowiada wysiłkom pracy, ani nieprodukcyjnie ponoszonym wydatkom ${ }^{95}$.

Wspominając o poematach dramatycznych, które w pełni mogą być wystawione tylko w teatrze wyobraźni czytelnika, Kotarbiński nawiązuje do cytowanego na początku tego artykułu stwierdzenia Byrona o niesceniczności jego utworów dramatycznych. Manfred ze swoimi długimi monologami nie miał wystarczająco dużo „tętna dramatycznego" i Kotarbiński z perspektywy czasu wydaje się zgadzać pod tym względem z krytykami przedstawienia w Teatrze Wielkim. Ewidentnie jako wielki miłośnik poezji romantycznej, mógł sądzić, że dzięki wprowadzeniu Manfreda z muzyką Schumanna na scenę Teatru Wielkiego, w ślad przedstawienia monachijskiego, zaznajomi z nią szerokie kręgi warszawskiej publiczności teatralnej. Mimo spektakularnej scenografii i oprawy muzycznej poezja Byrona na scenie była jednak atrakcyjna tylko dla nielicznych i nie zdołała przyciągnąc „,przeciętnego” widza.

\section{Bibliografia (References)}

A. Br. [Adam Breza], Manfred, Kurier Codzienny" 1892, r. 28, nr 73.

Alfa, Teatr i Muzyka. Wystawienie Byronowskiego „Manfreda” na scenie Teatru, „Przegląd Tygodniowy”, 1892, r. 27, nr 13, https://crispa.uw.edu.pl/object/ files/294778/display/Default (dostęp: 29.04.2021).

a.p. [Antoni Potocki?] Głosy, „Głos” 1892, r. 7, nr 12, https://polona.pl/item/glostygodnik-literacko-spoleczno-polityczny-r-7-nr-12-19-marca-1892,MTUyNTkw OTc/0/\#info:metadata (dostęp: 29.04.2021).

B. Lut. [Bolesław Lutomski], Kronika miesięczna, „Ateneum” 1892, t. 2 (66), z. 1.

Baines P., Burns E., The Playhouses of London, 1768-1821 [w:] Five Romantic Plays, red. P. Baines, E. Burns, Oxford 2000.

Bajron w życiu i na scenie, „Biesiada Literacka” 1892, nr 14, s. 218.

Bardzka, M, Manfred i Faust, ,Tygodnik Ilustrowany” 1892, seria 5, t. 5, nr 111.

Bieńka M.O., Od zenitu do zmierzchu. Teatr warszawski 1880-1919, Warszawa 2015.

Bieńka M.O., Warszawskie teatry rządowe. Dramat i komedia 1890-1915, Warszawa 2003.

Bond G., Kenyon-Jones C., Dangerous to Show. Byron and His Portraits, London 2020.

Bogusławski W., Felieton Teatralny. „Manfred” Byrona, z muzyka Schumanna, „Gazeta Polska” 1892, nr 59-60.

Bogusławski W., Poezja w teatrze, „Biblioteka Warszawska”, 1892, t. 2.

\footnotetext{
95 Ibid., s. 23.
} 
Burwick F., Staging Manfred [w:] On the 200 Anniversary of Lord Byron's Manfred. A Collection of Commemorative Essays, red. O.F. Miranda, Romantic Circles, 2019, https://romantic-circles.org/praxis/manfred/praxis.2019.manfred.burwick. html (dostęp: 2.02.2021).

Byron's Letters and Journals, red. L.A. Marchand, t. 5, Cambridge 1976; t. 8, London 1978.

Byron G.G., Fragment z „,Manfreda” Byrona, „Kurier Codzienny” 1892, r. 28, nr 72, https://polona.pl/item/kurjer-codzienny-r-28-nr-72-12-marca-1892-dod-poranny, NDEzNjk5ODc/0/\#info:metadata (dostęp: 29.04.2021).

Byron G.G., Listy i pamiętniki, red. J. Żuławski, Warszawa 1960.

Byron G.G. Manfred [w:] The Complete Poetical Works, red. J.J. McGann, t. 4, Oxford 1986.

Byron G.G., Manfred. Musik von R. Schumann, Leipzig [n.d.], Library of Congress, https://www.loc.gov/item/2010667234/ (dostęp: 20.03.2021).

Byron G.G., ,, Manfred.” Poemat dramatyczny, przeł. G. Kempner, „Tygodnik Ilustrowany" 1892, seria 5, t. 5, nr 113.

Byron G.G., ,,Manfred” Lorda Byrona, przeł. G. Kempner. „Echo Muzyczne, Teatralne i Artystyczne" 1892, nr 441.

Byron G.G., Manfred. Poemat dramatyczny lorda Byrona, przeł. G. Kempner, „Niwa” 1892, r. 21, nr 7.

Chew S., Jr., The Dramas of Lord Byron, Göttingen 1915.

Cochran P., Manfred. An Edition of Manuscripts and a Collection of Essays, Newcastle upon Tyne 2015.

Erlich V., The Conception of the Poet in Krasinski and the Romantic Myth of the Artist, "Studies in Romanticism" 1962, t. 1, nr 4 (Summer), s. 193-208, (199-200). Jstor (dostęp: 18.10.2013).

Geck M., Robert Schumann: The Life and Work of a Romantic Composer, przeł. S. Spencer, Chicago 2012.

Głowiński M., Ekspresja i empatia. Studia o młodopolskiej krytyce literackiej, Kraków 1997.

Hutnikiewicz A., Młoda Polska, Warszawa 2004.

Jasińska Z., Józef Kotarbiński, Warszawa 1969.

Jellenta C. [Napoleon Hirschband], „Manfred” na scenie naszej, „Prawda” 1892, r. 12 , nr 12-13.

Kempner G., Byronowski Manfred, „Przegląd Tygodniowy” 1892, r. 27, nr 11.

Kenig J., Z teatru, ,Słowo” 1892, r. 11, nr 69.

Kotarbińska L., Wokót teatru. Moje wspomnienia, Warszawa 1939, https:/www.sbc.org. $\mathrm{pl} /$ dlibra/show-content/publication/edition/34364?id=34364 (dostęp: 1.09.2021).

Kotarbiński J. Art. nad., „Kurier Poranny”, 1891, r. 15, nr 279, s. 2, https://crispa. uw.edu.pl/object/files/133709/display/Default (dostęp: 20.03.2021).

Kotarbiński J., Byrona „Don Juan” i Stowackiego „Beniowski”, „Ateneum” 1889, r. 14, t. 2, z. 1-2 [wg CRISPA 4-5], s. 12, https://crispa.uw.edu.pl/object/ files/410142/display/Default (dostęp: 29.04.2021). 
Kotarbiński J., Listydo redakcji ,, Słowa”, ,Słowo” 1891, r. 10, nr 224, https://polona.pl/ item/slowo-r-10-nr-224-9-pazdziernika-1891,MTU3NjI3NzU/0/\#info:metadata (dostęp: 30.03.2021).

Kotarbiński J., Listy do redakcji, „Kurier Codzienny” 1891, r. 27, nr 278, s. 2, https:// polona.pl/item/kurjer-codzienny-r-27-nr-278-8-pazdziernika-1891,NDEwMzgy MDc/0/\#info:metadata (dostęp: 30.03.2021).

Kotarbiński J., W stużbie sztuki i poezji, Warszawa 1929.

Kotarbiński J., Ze świata ułudy. Wybór pism teatralnych, wybór i opracowanie D. Kosiński, Kraków 2012.

Krajewska W., Recepcja literatury angielskiej w Polsce $w$ okresie modernizmu (1887-1918), Wrocław 1972.

Krzyżanowski J., Neoromantyzm polski 1890-1918, wyd. 3, Wrocław 1980.

Lange A., Poezje, część II, Kraków 1898.

Lewandowski T., Cezary Jellenta, estetyk i krytyk. Działalność w latach 1880-1914, Wrocław 1975.

Leo A., Wczoraj. Gawęda z niedawnej przeszłości, Warszawa 1929.

Lessenich R.P., Drama and Theater [w:] Byron in Context, red. C. Tuite, Cambridge 2020.

Liszt F., Franz Liszt's Briefe, red. La Mara [I.M. Lipsius], t. 1, Leipzig 1893, GoogleBooks.

Lubowski E., ,, Manfred” dramat w 4-ch aktach Byrona, muzyka Roberta Schumanna. $Z$ oryginatu przełożyt $i$ do sceny przystosowat Gabryel Kempner. Przeglad teatralny, ,Tygodnik Ilustrowany” 1892, seria 5, t. 5, nr 116.

Manfred. THEATREONLINE.com, https://www.theatreonline.com/Spectacle/Manfred/43084 (dostęp: 30.04.2021).

M. [A. Mieszkowski], Przeglad teatralny, „Wiek: gazeta polityczna, literacka i społeczna" 1892, r. 20, nr 58, https://crispa.uw.edu.pl/object/files/251401/display/PDF (dostęp: 29.04.2021).

M.G. [M. Gawalewicz], Z tygodnia na tydzień, „Tygodnik Ilustrowany” 1892, seria 5, t. 5, nr 116.

Manning P.J., Byron and His Fictions, Detroit 1978.

Manning P.J., Edmund Kean and Byron's Plays. „Keats-Shelley Journal” 1972/1973, t. $21 / 22$.

Maresz B., Władysław Bogusławski, Encyklopedia teatru polskiego, http://www.encyklopediateatru.pl/osoby/4999/wladyslaw-boguslawski (dostęp: 2.09.2021).

Noskowski Z., Muzyka w ,Manfredzie”. Przegląd teatralny, „Wiek: gazeta polityczna, literacka i społeczna" 1892, r. 20, nr 58, https://crispa.uw.edu.pl/object/ files/251401/display/PDF (dostęp: 29.04.2021).

P., Teatr (Manfred), „Gazeta Warszawska” 1892, r. 119, nr 69.

Pakowska R., Polskie przekłady poematów Byrona „,Childe Harold” i „Manfred”, Kraków 1938.

Podraza-Kwiatkowska M., Literatura Młodej Polski, Warszawa 2000.

Poliński A., ,,Manfred” [rec. muzyki]. Z teatru, „Kurier Poranny” 1892, r. 16, nr 71. Prus B., Kronika tygodniowa (Awantura z powodu Manfreda), „Kurier Codzienny” 1892 , r. 28, nr 85, s. 1.

Prus B., Kroniki, red. Z. Szweykowski, t. 13, Warszawa 1963. 
Rajchman A., Manfred. Poemat dramatyczny lorda Byrona. „Echo Muzyczne, Teatralne i Artystyczne" 1892, nr 442.

Reitz B., Byron's Praise of Sheridan [w:] Byron as Reader, red. P. Bridzun, F.E. Pointner, Essen 1999, s. 2.

Richardson A., A Mental Theater. Poetic Drama and Consciousness in the Romantic Age, University Park and London 1988.

Seymour M., In Byron's Wake. The Turbulent Lives of Lord Byron's Wife and Daughter: Annabella Milbanke and Ada Lovelace, London 2018.

Sęp [Władysław Maleszewski], Z Warszawy, „Biesiada Literacka” 1892, t. 33, nr 12.

Słowacki J., Kordian [w:] Dzieła wybrane, t. 3: Dramaty, red. E. Sawrymowicz, Wrocław 1974.

Słownik pseudonimów pisarzy polskich XV w. - 1970 r., t. 1-4, red. E. Jankowski, Wrocław 1994-1996.

Sobieraj T., Polska krytyka $i$ myśl teatralna $w$ drugiej połowie XIX wieku. Studia i szkice, Kraków 2014.

Spasowicz W., Byron i niektórzy jego poprzednicy [w:] Pisma, t. 2, Petersburg 1892.

Szweykowski Z., Twórczość Bolesława Prusa, Warszawa 1972.

Szydłowska M., Józef Kotarbiński [w:] Encyklopedia teatru polskiego, 2018, https:// www.encyklopediateatru.pl/osoby/26730/jozef-kotarbinski (dostęp:16.03.2021).

Thorslev P.L., Jr., The Byronic Hero. Types and Prototypes, Minneapolis 1962.

Tunbridge L., Schumann as Manfred, „The Musical Quarterly” 2004, t. 87, nr 3, s. 546-569, http://search-1ebscohost- 1com-1h9xsv2vl0152.hps.bj.uj.edu.pl/ login.aspx?direct=true \&db=edsjsr\&AN=edsjsr.3600936\&site=eds-live (dostęp: 29.03.2021).

Tunbridge L., Schumann's Manfred in the Mental Theatre, „Cambridge Opera Journal" 2003, t. 15, nr 2, s. 153-183, doi:10.1017/S0954586703001678 (dostęp: 29.03.2021).

Windakiewicz S., Walter Scott i Lord Byron w odniesieniu do polskiej poezji romantycznej. Kraków 1914.

Wyka K., Młoda Polska. Tom 1: Modernizm polski, wyd. II, Kraków 1987.

X. [Adam Wiślicki?], „Przegląd Tygodniowy” 1892, r. 27, nr 24.

Zalewski K., Z teatru (Dokończenie), „Kurier Warszawski” 1891, r. 71, nr 271, s. 2, https://crispa.uw.edu.pl/object/files/163105/display/Default (dostęp: 30.03.2021).

Zalewski K., Z teatru, „Kurier Warszawski” 1892, nr 74-75.

Z powodu Manfreda, „Kurier Poranny” 1892, r.16, nr 74, s. 5, https://crispa.uw.edu.pl/ object/files/133552/display/Default (dostęp: 25.10.2021).

Z teatru. „Kurier Poranny” 1892, r. 16, nr 74, s. 3, https://crispa.uw.edu.pl/object/ files/133552/display/Default (dostęp: 25.10.2021).

$Z$ teatru, „Kurier Poranny 1892, r. 16, nr 37, s. 3, https:/crispa.uw.edu.pl/object/ files/133577/display/Default (dostęp: 25.10.2021). 
Z teatru. Manfred, „Kurier Poranny” 1892, r. 16, nr 71, s. 3-4, https://crispa.uw.edu. pl/object/files/133555/display/Default (dostęp: 25.10.2021).

(.) Z teatru. Manfred, „Kurier Poranny” 1892, r. 16, nr 73, s. 4-5, https://crispa. uw.edu.pl/object/files/133553/display/Default (dostęp: 25.10.2021).

Autorka składa serdeczne podziękowania za cenne uwagi i sugestie dr hab. Annie Pekaniec. 